\title{
Nerve Growth Factor and Ras Regulate $\beta$-Amyloid Precursor Protein Gene Expression in PC12 Cells
}

\author{
José Miguel Cosgaya, Maria Jesús Latasa, and Angel Pascual \\ Instituto de Investigaciones Biomédicas, Consejo Superior de Investigaciones Científicas, Madrid, Spain
}

\begin{abstract}
The $\beta$-amyloid protein, the major component of the vascular and plaque amyloid deposits that characterize Alzheimer's disease, derives from a larger $\beta$-amyloid precursor protein (APP) that is expressed in both neural and nonneural cells. An increased expression of APP might actively contribute to the development of the pathology; however, the mechanisms involved in the regulation of APP gene expression are not yet well understood. In PC12 cells, a rat pheochromocytoma cell line, we have demonstrated that nerve growth factor (NGF) induces the APP gene expression and increases APP mRNA levels in the presence of 0.5 or $15 \%$ serum. Expression of activated ras in the PC12 cell subline UR61 also leads to a significant increase in content of APP transcripts, and a dominant negative mutant of ras blocks the NGF-induced response. Other ligands of tyrosine kinase receptors, such as fibroblast growth factor, which causes morphological differentiation, or epidermal growth factor, which induces cell growth, also increase APP mRNA levels in PC12 cells. These results suggest that ras mediates the induction of APP gene expression by NGF and other ligands of tyrosine kinase receptors. Key Words: Amyloid precursor protein-PC12 cellsras oncogene-Growth factors-Tyrosine kinase receptors.

J. Neurochem. 67, 98-104 (1996).
\end{abstract}

Alzheimer's disease is a progressive and irreversible disorder of the human CNS that is associated with specific neuropathological lesions, including intracellular neurofibrillary tangles and the progressive deposition of fibrillar aggregates of amyloid protein throughout the brain. The major component of the amyloid deposits, a hydrophobic 39-43-amino-acid peptide, is proteolytically derived from a larger membrane protein, the $\beta$-amyloid precursor protein (APP), which is encoded by a gene located on human chromosome 21 (for a review, see Selkoe, 1994).

Because the APP gene plays a central role in Alzheimer's disease, an anomaly of its expression might contribute to its development. The appearance of a pathology similar to Alzheimer's disease in Down's syndrome, or trisomy 21 , is correlated with increased levels of APP mRNA, which result at least in part from duplication of the APP gene (Neve et al., 1988). This finding, as well as the degeneration of neurons overexpressing APP (Yoshikawa et al., 1992) or the appearance of $\beta$-amyloid-immunoreactive deposits in transgenic mice carrying the human APP cDNA (Quon et al., 1991; Games et al., 1995), strongly suggests that overexpression of the APP gene is directly involved in the formation of amyloid deposits and development of Alzheimer's disease.

APP is ubiquitously expressed in mammalian tissues, with brain and kidney having the highest levels. APP expression is induced in different cell types by various cellular mediators, including nerve growth factor (NGF) (Mobley et al., 1988; König et al., 1990; Ohyagi and Tabira, 1993), basic fibroblast growth factor (bFGF) (Quon et al., 1990), interleukin-1 (Goldgaber et al., 1989), retinoic acid (König et el., 1990), or phorbol esters (Yoshikai et al., 1990; Trejo et al., 1994).

NGF is one of the most well-characterized neurotrophic factors in vitro as well as in vivo (for a review, see Levi-Montalcini, 1987), and the signal transduction pathways that mediate the cellular events induced by this factor have been extensively studied. The effects induced by NGF and other growth factors such as fibroblast growth factor (FGF) or epidermal growth factor (EGF) are mediated by tyrosine kinase receptors. On binding of the corresponding ligand the receptors stimulate a cascade of intracellular signals that control biochemical pathways leading to changes in gene expression (for a review, see Schlessinger, 1993 ). PC12 cells, a rat pheochromocytoma cell line (Greene and Tischler, 1976), have been useful in analyzing the molecular mechanisms of the actions of NGF. Ligand activation of the NGF receptor leads to

Received October 23, 1995; revised manuscript received February 21, 1996; accepted February 23, 1996.

Address correspondence and reprint requests to Dr. A. Pascual at Instituto de Investigaciones Biomédicas, Consejo Superior de Investigaciones Científicas, Arturo Duperier 4, 28029 Madrid, Spain.

Abbreviations used: APP, $\beta$-amyloid precursor protein; bFGF, basic fibroblast growth factor; EGF, epidermal growth factor; FGF, fibroblast growth factor; MAPK, mitogen-activated protein kinase; NGF, nerve growth factor. 
biochemical and morphological changes characteristic of sympathetic neuronal differentiation, including neurite extension, cessation of cell division, and expression of neuronal-specific genes (Halegoua et al., 1991). FGF mimics many of the effects of NGF and induces growth arrest and neurite extension (Togari et al., 1983), whereas EGF promotes cell growth (Huff et al., 1981; Rabin et al., 1993).

The products of the ras protooncogenes are small proteins that bind guanine nucleotides, and there is strong evidence that these proteins play an important role in signal transduction from various receptors that belong to the tyrosine kinase family of receptors. Expression of oncogenic mutant ras in $\mathrm{PC} 12$ cells results in neuronal differentiation (Bar-Sagi and Feramisco, 1985; Guerrero et al., 1988), whereas microinjection of anti-Ras antibodies reverses NGF-induced neurite outgrowth (Hagag et al., 1986; Kremer et al., 1991), and a dominant inhibitory Ras mutant blocks morphological differentiation induced by NGF or FGF (Szeberényi et al., 1990; Kremer et al., 1991). Furthermore, these growth factors increase the amount of active GTP-bound Ras (Muroya et al., 1992), and the protooncogene mediates the NGF modulation of different signal-transducing protein kinases, including the mitogen-activated protein kinase (MAPK) cascade (Thomas et al., 1992; Wood et al., 1992).

NGF has been found to increase APP mRNA expression in SH-SY5Y human neuroblastoma cells (König et al., 1990), in primary cultures prepared from mouse whole brain (Ohyagi and Tabira, 1993), and in developing hamster brain (Mobley et al., 1988). By contrast, NGF does not influence the expression of APP mRNA in the rat septal/nucleus basalis system (Forloni et al., 1993). In PC12 cells, the APP is constitutively expressed, and NGF has been reported to affect differentially the expression of the distinct APP isoforms that are produced by alternative splicing of the primary transcript (Fukuyama et al., 1993). Also, in PC12 cells, NGF modulates the posttranslational processing and induces the secretion of APP in cell culture (Refolo et al., 1989). However, the mechanisms by which NGF controls the expression of the APP gene have not yet been examined.

In this work we have examined the possibility that activation of Ras could play a role in the regulation of APP gene expression by NGF and other ligands of the tyrosine kinase receptors in $\mathrm{PC} 12$ cells. Our results show that NGF induces an increase in APP mRNA levels in PC12 cells. Expression of activated ras has a similar effect, and a dominant negative mutant of the ras protooncogene inhibits activation of APP gene expression by NGF. These results strongly suggest that NGF might increase APP mRNA levels in PC12 cells by a mechanism that involves the Ras pathway. EGF and bFGF also activate Ras in PC12 cells (Qiu and Green, 1992), and both factors are able to induce APP gene transcripts in PC12 cells.

\section{MATERIALS AND METHODS}

\section{Cell cultures}

PC12 cells were cultured in RPMI medium containing $10 \%$ donor horse serum (Quality Biological) and 5\% fetal calf serum (GIBCO) in collagen-treated plates. The subclones of $\mathrm{PC} 12$ cells, UR61 and M-M17-26 cells, were grown in a similar medium containing $10 \%$ horse serum and $5 \%$ fetal calf serum. UR61 cells were derived from PC12 cells following transfection with a plasmid containing the transformant mouse N-ras oncogene under the transcriptional control of the dexamethasone-inducible mouse mammary tumor virus promoter (Guerrero et al., 1988). The PC12 subline M-M17-26 was obtained by Szeberényi et al. (1990) after transfection with the dominant negative mutant Ha-ras $\left(A s n^{17}\right.$ ) gene transcribed from the promoter of the mouse metallothionein-1 gene.This subclone constitutively expresses high levels of mutant Ras protein that could not be further induced by zinc.

The PC12 subclones were incubated with the different factors at the concentrations and for the times indicated in the figures. The incubations were carried out either in highserum conditions (the medium indicated above) or in lowserum conditions (medium containing $0.5 \%$ of a $2: 1$ mixture of donor horse serum/fetal calf serum). NGF and dexamethasone were obtained from Sigma, and bFGF and EGF were obtained from Austral Biologicals.

\section{RNA extraction and hybridization}

Total RNA was extracted from the cell cultures with guanidinium thiocyanate (Chomczynski and Sacchi, 1987). The RNA was electrophoresed in $1 \%$ formaldehyde-agarose gels and transferred to nylon-nitrocellulose membranes (Nytran) for northern blot analysis. The RNA was stained with $0.02 \%$ methylene blue. The blots were hybridized with a plasmid containing a human APP cDNA labeled by random oligonucleotide priming. Hybridizations were at $42^{\circ} \mathrm{C}$ with $50 \%$ formamide, and the more stringent wash was at $42^{\circ} \mathrm{C}$ with $0.1 \times$ saline-sodium citrate containing $0.1 \%$ sodium dodecyl sulfate. The mRNA levels were quantified by densitometric scan of the autoradiograms. The values obtained were corrected by the amount of RNA applied in each lane, which was determined by densitometry of the stained membranes.

\section{RESULTS}

\section{Effect of NGF on expression of the APP gene}

Figure 1 illustrates a northern blot analysis with total RNA obtained from PC12 cells after different intervals of treatment with NGF $(50 \mathrm{ng} / \mathrm{ml})$ in the presence of 0.5 or $15 \%$ serum. In both cases a unique band of APP mRNA was observed in the range of $3.3 \mathrm{~kb}$. Under low-serum conditions a small increase in content of APP mRNA is already observed after only $10 \mathrm{~h}$ of treatment, and a maximal response (two- to threefold) is observed at $48 \mathrm{~h}$. In the presence of $15 \%$ serum the response to NGF is more remarkable, reaching a fivefold increase above the values found in the control group. However, the response is delayed under these conditions, and no differences are observed before 48 $h$ of treatment. In the absence of NGF, APP mRNA levels did not vary between 0 and $72 \mathrm{~h}$ in cells grown with either 0.5 or $15 \%$ serum (data not shown). 

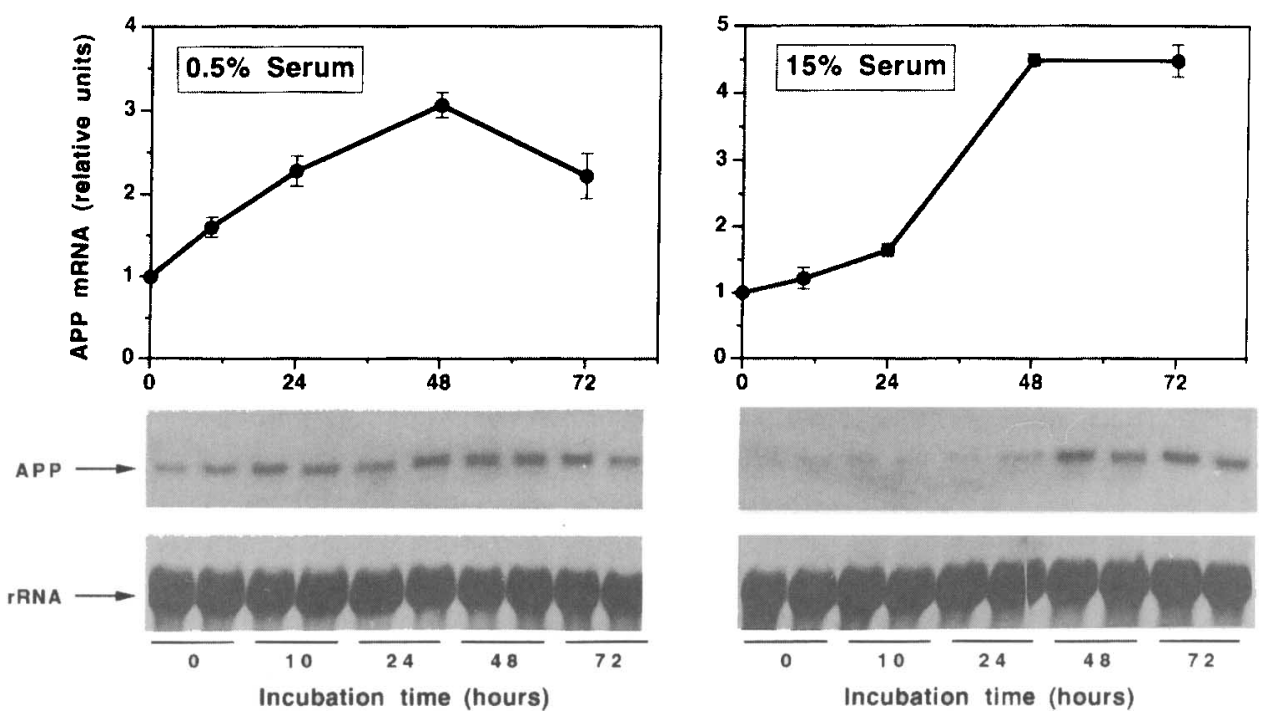

FIG. 1. Induction of APP mRNA by NGF in PC12 cells. Cells were incubated with $50 \mathrm{ng} / \mathrm{ml}$ of NGF in 0.5 (left) or $15 \%$ (right) serum. At the indicated times cells were harvested, and $30 \mu \mathrm{g}$ of total RNA was processed for northern blot analysis as described in Materials and Methods. Top panels: Quantification of these results. APP mRNA levels were determined by densitometric scan of autoradiograms and corrected by the amount of RNA applied. Data are expressed as fold induction above the levels found in control cells and represent mean \pm SD (bars) values of four determinations (duplicates from two separate assays). The 3.3-kb APP mRNA bands from the autoradiogram and the 18S rRNA from the stained blots are illustrated in the middle and bottom panels, respectively. Control values correspond to APP mRNA of cells harvested at $48 \mathrm{~h}$ in the experiments.

\section{Implication of the ras protooncogene in regulation of APP expression by NGF}

Because various cellular responses to NGF are mediated by the ras protooncogene products, we have examined the effect of activated Ras on APP gene expression in a PC12 cell subline (UR61) that contains a transfected ras oncogene under control of the inducible MMTV promoter. Figure 2A shows the levels of APP transcripts in these cells after different times of incubation with dexamethasone in the presence of $15 \%$ serum. Incubation of UR61 cells with $100 \mathrm{n} M$ dexamethasone leads to a two- to threefold increase in the levels of APP mRNA that is observed as early as $3 \mathrm{~h}$ and is maintained until $72 \mathrm{~h}$. Presumably this induction is the result of the previous induction of the ras transcript that is detected after $1-2 \mathrm{~h}$ of treatment with dexamethasone (Guerrero et al., 1988). However, to discount a direct effect of the glucocorticoid on APP gene we have also examined the effect of $100 \mathrm{n} M$ dexamethasone on APP mRNA levels in PC12 cells. As shown in Fig. 2B, dexamethasone does not elevate the levels of APP transcripts in the parental cell line. These results demonstrate that in UR61 cells activated Ras is responsible for the stimulation of APP gene expression by the steroid. In these cells the induction of APP gene expression by NGF was quantitatively similar to that observed with Ras, increasing APP mRNA levels to two- to 2.5 -fold over control values between 8 and 48 h (data not shown).

To determine whether the endogenous Ras is required for stimulation of APP gene expression by NGF, we analyzed the ability of the growth factor to increase levels of APP mRNA in PC12 (M-M17-26) cells, which express a dominant negative Ras mutant. Figure 3 illustrates APP mRNA levels obtained in the ras dominant negative cells after incubation with $50 \mathrm{ng} /$ $\mathrm{ml}$ of NGF for 8 and $48 \mathrm{~h}$ in the presence of either 0.5 (left panel) or $15 \%$ (right panel) serum. Under both serum conditions the levels of the transcripts are not stimulated by NGF in M-M17-26 cells. These results support the hypothesis that induction of APP gene expression by NGF involves a signal transduction pathway that requires the activity of Ras proteins.

\section{Induction of APP mRNA by other ligands of tyrosine kinase receptors}

We have also analyzed the effect of other growth factors such as FGF, EGF, insulin-like growth factor1 , or platelet-derived growth factor on the expression of the APP gene in PC12 cells. Figure 4 shows a northern blot analysis of RNA obtained from $\mathrm{PC} 12$ cells treated for $16 \mathrm{~h}$ with $17 \mathrm{ng} / \mathrm{ml}$ of bFGF and $60 \mathrm{ng} / \mathrm{ml}$ of EGF. A significant and similar increase (threefold induction ) of APP mRNA levels is observed with both growth factors. A lower but detectable ( 1.5 -fold induction) APP response is induced by $8 \mathrm{ng} / \mathrm{ml}$ of insulinlike growth factor- 1 , whereas $10 \mathrm{ng} / \mathrm{ml}$ of plateletderived growth factor did not elicit any increase over the control levels of APP mRNA (data not shown).

\section{DISCUSSION}

In this study we have examined the activation of the APP gene in three variants of PC12 cells: the parental 
A) UR61 cells

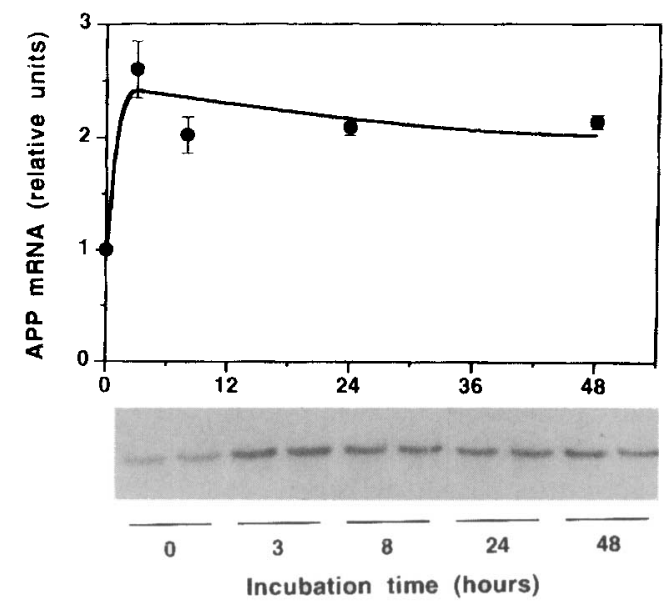

B) PC12 cells

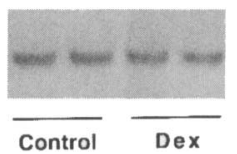

FIG. 2. Regulation of APP mRNA levels by Ras. A: Autoradiogram (bottom panel) and densitometric determination of mRNA levels of a representative northern blot carried out with $25 \mu \mathrm{g}$ of RNA extracted from UR61 cells exposed to dexamethasone (100 $\mathrm{n} M)$ for the indicated times. APP mRNA bands from the autoradiograms were quantified by scan densitometry and corrected by the amount of RNA applied. The results, expressed as fold induction over the control levels, are shown in the top panel. Data are mean \pm SD (bars) values. B: Autoradiogram corresponding to a northern blot with RNA extracted from PC12 cells after $24 \mathrm{~h}$ of incubation in the absence (control) or the presence of dexamethasone (Dex). In both cases $15 \%$ serum was present in the culture medium. cell line and two different subclones, one overexpressing the $\mathrm{N}$-ras oncogene (UR61 cells) and the other (M-M17-26 cells ) containing a dominant inhibitory mutant of ras. In agreement with results obtained by other groups in different cell types (Mobley et al., 1988; König et al., 1990; Ohyagi and Tabira, 1993), we have observed that NGF induces APP gene expression in PC12 cells. In this cell line it has been also described that NGF specifically increases levels of the $\mathrm{APP}^{695}$ transcript and the release of this protein to the medium (Refolo et al., 1989). In addition, it has been shown that NGF differentially regulates the localization of APP within these cells (Fukuyama et al., 1993).

Our results show that the NGF-mediated APP mRNA response in $\mathrm{PC} 12$ cells is dependent on the amount of serum present in the culture media. Under low-serum conditions, a detectable increase in content of APP transcripts is already observed after $10 \mathrm{~h}$ of incubation with the growth factor, and the increase reaches a two- to threefold induction after $24 \mathrm{~h}$ of incubation. By contrast, in the presence of $15 \%$ serum the response to NGF treatment is delayed, and no differences are observed before $48 \mathrm{~h}$. The increase is, however, stronger than that observed under low-serum conditions, reaching a four- to fivefold induction between 48 and $72 \mathrm{~h}$ of treatment. The different induction of APP mRNA observed in both cases suggests the presence of still unidentified factors in the serum that can regulate the transcription of the APP gene and affect the NGF response.

Several second messenger pathways are activated in response to NGF. However, no causal relationship has been established between the activated second messenger systems and many of the observed actions. An increasing body of evidence suggests the involvement of the ras gene product $\mathrm{p} 21$ in the NGF-triggered signal
FIG. 3. Effects of NGF on APP mRNA levels in M-M17-26 cells, which express a dominant negative Ras mutant. Total RNA was extracted after incubation with $50 \mathrm{ng} / \mathrm{ml}$ of NGF for the indicated times, in the presence of either 0.5 or $15 \%$ serum. Northern blot analysis was carried out with $25 \mu \mathrm{g}$ of total RNA. Bands from the autoradiogram and stained blots from the filter membrane were quantified by densitometric scanning. The APP mRNA levels, corrected by the amount of rRNA applied and expressed as relative units, are illustrated in the top panels Data are mean \pm SD (bars) values.

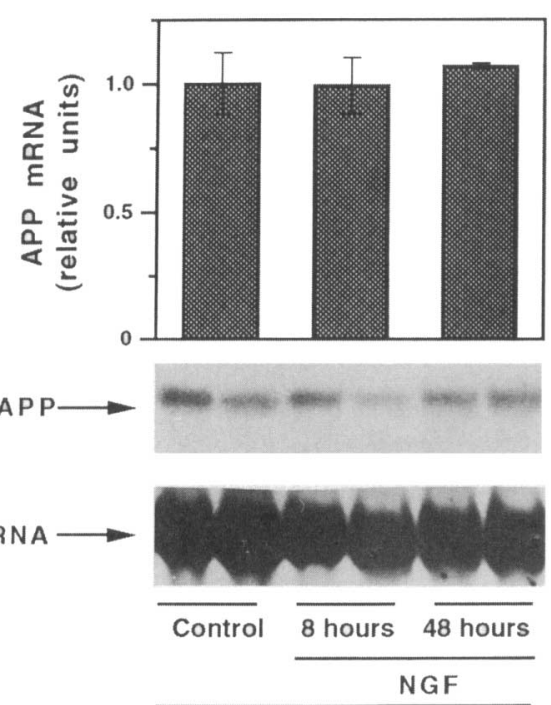

$0.5 \%$ Serum
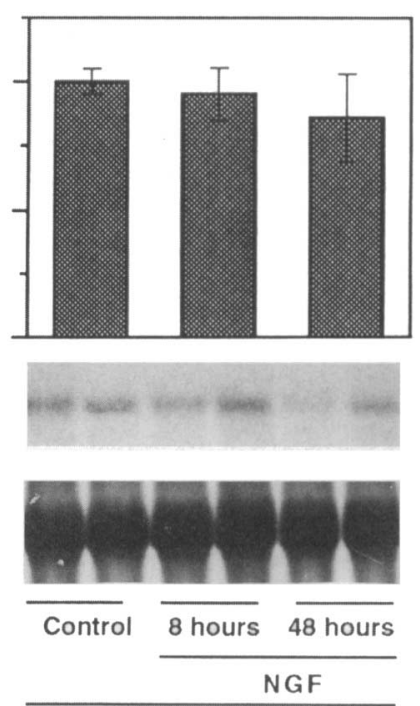

$15 \%$ Serum 


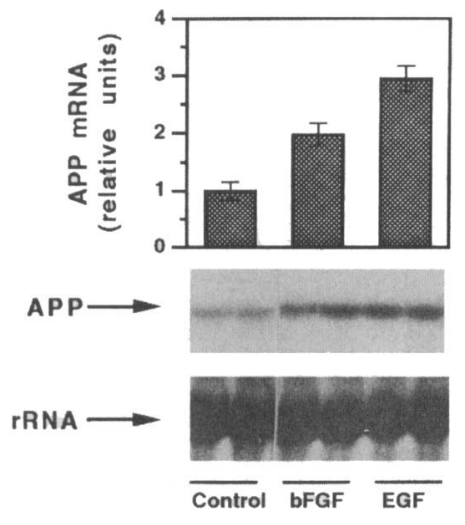

FIG. 4. Induction of APP mRNA by ligands of tyrosine kinase receptors. APP mRNA levels were determined by northern blot analysis in PC12 cells after $16 \mathrm{~h}$ of incubation with or without bFGF $(17 \mathrm{ng} / \mathrm{ml})$ or EGF $(60 \mathrm{ng} / \mathrm{ml})$ under low-serum conditions. APP mRNA bands from the autoradiogram and $18 \mathrm{~S}$ rRNA bands from the filter membrane are shown in the middle and bottom panels, respectively. Top panel: Densitometric quantification of APP mRNA bands. Values are corrected by the corresponding amount of rRNA and expressed as fold induction over control levels. Data are mean $\pm S D$ (bars) values.

transduction pathway. To examine whether or not the Ras system is involved in the regulation of APP expression, we have studied the induction of APP mRNA by oncogenic Ras in the UR61 cell line. Treatment of UR61 cells with dexamethasone results in a rapid and sustained increase in content of APP transcripts. In the UR61 subclone of PC12 cells, the transfected ras protooncogene is under control of a dexamethasoneinducible MMTV promoter. Because the glucocorticoid is unable to induce APP RNA in the parental PC12 cells, it can be assumed that Ras is the signal transduction pathway used by dexamethasone to increase levels of APP transcripts in UR61 cells.

Evidence that activation of endogenous Ras could play a crucial role in the signal transduction of NGF that leads to APP gene expression comes from the experiments with a PC12 subclone (M-M17-26) expressing the dominant inhibitory mutant Ras $\left(\mathrm{Asn}^{17}\right.$ ) (Szeberényi et al., 1990). This mutant has a reduced affinity for GTP, and inhibition of endogenous Ras function by this mutant has been suggested to occur through competition with normal Ras for regulatory proteins that promote nucleotide exchange (Feig and Cooper, 1988). Studies on the effects of Ras have demonstrated that the Asn ${ }^{17}$ mutation is located in the effector-binding motif, and therefore such a mutation might disrupt the structure necessary for Ras to bind to the effector proteins, such as c-Raf- 1 and phosphatidylinositol-3-hydroxy kinase, that are believed to be responsible for transmitting the growth and differentiation signals of growth factors (Warne et al., 1993; Rodriguez-Viciana et al., 1994). Szeberényi et al. (1990) have shown that the mutant blocks the neurite outgrowth induced by NGF of FGF, as well as the induction of different genes.
The M-M17-26 cell line has been widely accepted as a good model to investigate the role of Ras in NGFmediated signal transduction in PC12 cells, and it has been useful to demonstrate that Ras proteins are involved in PC12 differentiation (Szeberényi et al., 1990). Our results demonstrate that expression of the dominant inhibitory mutant of Ras blocks the induction of APP gene expression by NGF, thus suggesting the requirement for a functional Ras signaling pathway for this response. Possible damage of the enzymatic machinery functioning downstream of ras has not been excluded by our results in the M-M17-26 Ras dominant negative-containing cells. However, in these cells the main Ras-dependent pathway has been described as being functional, at least downstream of Raf (Troppmair et al., 1992). Further studies are necessary to clarify the specific role of Ras as well as the involvement of effector proteins such as Raf or phosphatidylinositol-3-hydroxy kinase in APP gene expression.

Different ligands of tyrosine kinase receptors have neurotrophic or mitogenic effects in PC12 cells, and it has been also shown that growth factors can activate Ras by increasing the level of Ras-GTP in these cells (Qiu and Green, 1992). In this study we have shown that FGF, which causes morphological differentiation, and EGF, which promotes cell growth, induce a significant increase in content of APP mRNA. Insulinlike growth factor-1, another ligand of tyrosine kinase receptors that activates ras, also induces this mRNA, although with less potency. These results strongly suggest that APP gene expression is regulated by NGF and other ligands of tyrosine kinase receptors by a mechanism that involves the previous activation of Ras. In agreement with the absence of platelet-derived growth factor receptors in PC12 cells (Heasly and Johnson, 1992), this factor does not induce APP transcripts in these cells.

The $5^{\prime}$ promoter region of the APP gene has been cloned and characterized for both humans (Salbaum et al., 1988; Lahiri and Robakis, 1991) and rodents (Hoffman and Chernak, 1994), and it has been well documented that it contains numerous regulatory regions, including an AP-1 site. It has been shown that the phorbol ester-induced transcriptional activation of the APP gene is mediated by a mechanism that involves the activation of protein kinase $\mathrm{C}$ and expression of the transcription factor Jun/AP-1 (Trejo et al., 1994). Because NGF, as well as FGF and EGF, induces a Ras-dependent expression of this transcription factor in PC12 cells (Greenberg et al., 1985), it is possible that the AP-1 element could be involved in the regulation of the APP gene by these growth factors.

Evidence of a mutual relationship between the APP and Ras-mediated actions of NGF is emerging. In PC12 cells, APP might be acting as a mediator of the effects of NGF on neurite outgrowth (Milward et al., 1992), and a direct effect of the secreted forms of APP on neurite extension has been recently described in cortical neurons in culture (Allinquant et al., 1995). 
The induction of neurite outgrowth by NGF is blocked in the presence of antibodies directed against either APP (Milward et al., 1992) or Ras (Kremer et al., 1991 ), showing that both proteins are involved in the NGF-dependent induction of neurite outgrowth. In addition, it has been recently demonstrated that secreted forms of APP activate the Ras-dependent MAPK cascade in PC12 cells (Greenberg et al., 1994), which is also well known to be activated by NGF by a Rasdependent mechanism (Thomas et al., 1992; Wood et al., 1992).

Overexpression of the APP gene might be one of the mechanisms that more directly contributes to the development of Alzheimer's disease. An increased expression of this gene might result in an aberrant processing of the amyloid precursor, which leads to higher concentration of the amyloidogenic fragments that appear in the $\beta$-amyloid deposits of the brain (Fucuchi et al., 1992). Moreover, APP has been described as activating the MAPK cascade, which enhances the phosphorylation of the $\tau$ protein and promotes the formation of paired helical filaments (Greenberg et al., 1994). Therefore, overexpression of APP might also contribute to the development of this pathology through a mechanism that involves the formation of intracellular tangles. The APP gene plays a central role in Alzheimer's disease, and because an anomaly of its expression might contribute to the development of this pathology, efforts should be made to study the mechanisms involved in APP expression. Knowledge about the contribution of different growth factors to the control of APP gene expression would, it is hoped, help us to clarify the molecular mechanisms implicated in this pathology.

Acknowledgment: We thank G. M. Cooper and A. Pellicer for the PC12 subclones, and we also thank A. Aranda for valuable discussions. M. J. Latasa is recipient of a fellowship from the Departamento de Educación y Cultura del Gobierno de Navarra. This work has been supported by grants PB93-0135 from the DGICYT and FIS 94/0272.

\section{REFERENCES}

Allinquant B., Hantraye P., Mailleux P., Moya K., Bouillot C., and Prochiantz A. (1995) Downregulation of amyloid precursor protein inhibits neurite outgrowth in vitro. J. Cell Biol. 128, 919-927.

Bar-Sagi D. and Feramisco J. R. (1985) Microinjection of the Ras oncogene protein into PC12 cells induces morphological differentiation. Cell 42, 841-848.

Chomczynski P. and Sacchi N. (1987) Single-step method of RNA isolation by acid guanidinium thiocyanate-phenol-chloroform extraction. Anal. Biochem. 162, 156-159.

Feig L. A. and Cooper G. M. (1988) Inhibition of NIH 3 T3 cell proliferation by a mutant Ras protein with preferential affinity for GDP. Mol. Cell. Biol. 8, 3235-3243.

Forloni G., Del Bo R., Angeretti N., Smiroldo S., Gabellini N., and Vantini G. (1993) Nerve growth factor does not influence the expression of $\beta$-amyloid precursor protein mRNA in rat brain: in vivo and in vitro studies. Brain Res. 620, 292-296.

Fucuchi K., Kamino K., Deeb S. S., Smith A. C., Dang T., and Martin G. M. (1992) Overexpression of amyloid precursor pro- tein alters its normal processing and is associated with neurotoxicity. Biochem. Biophys. Res. Commun. 182, 165-173.

Fukuyama R., Chandrasekaran K., and Rapoport S. I. (1993) Nerve growth factor-induced neuronal differentiation is accompanied by differential induction and localization of the amyloid precursor protein (APP) in PC12 cells and variant PC12S cells. $\mathrm{Mol}$. Brain Res. 17, 17-22.

Games D., Adams D., Alessandrini R., Barbour R., Berthelette P., Blackwell C., Carr T., Clemens J., Donaldson T., Gillespie F., Guido T., Hagoplan S., Johnson-Wood K., Khan K., Lee M., Leibowith P., Lieberburg I., Little S., Masliah E., McConlogue L., Montoya-Zavala M., Mucke L., Paganini L., Penniman E., Power M., Schenk D., Seubert P., Snyder B., Soriano F., Tan H., Vitale J., Wadsworth S., Wolozin B., and Zhao J. (1995) Alzheimer-type neuropathology in transgenic mice overexpressing V717F $\beta$-amyloid precursor protein. Nature 273, 523527.

Goldgaber D., Harris H. W., Hla T., Maciag T., Donnelly R. J., Jacobsen J. S., Vitek M. P., and Gajdusek D. C. (1989) Interleukin 1 regulates synthesis of amyloid $\beta$-protein precursor mRNA in human endothelial cells. Proc. Natl. Acad. Sci. USA 86, $7606-7610$.

Greenberg M. E., Greene L. A., and Ziff E. B. (1985) Nerve growth factor and epidermal growth factor induce a rapid transient change in proto-oncogene transcription in $\mathrm{PC} 12$ cells. J. Biol. Chem. 260, 14101-14110.

Greenberg S. M., Koo E. H., Selkoe D. J., Qiu W. Q., and Kosik K. S. (1994) Secreted $\beta$-amyloid precursor protein stimulates mitogen-activated protein kinase and enhances $\tau$ phosphorylation. Proc. Natl. Acad. Sci. USA 91, 7104-7108.

Greene L. A. and Tischler A. (1976) Establishment of a noradrenergic clonal line of rat adrenal pheochromocytoma cells which respond to nerve growth factor. Proc. Natl. Acad. Sci. USA 73, 2424-2428.

Guerrero I., Pellicer A., and Burstein D. E. (1988) Dissociation of c-fos from ODC expression and neuronal differentiation in a PC-12 subline stably transfected with an inducible N-ras oncogene. Biochem. Biophys. Res. Commun. 150, 1585-1592.

Hagag N., Halegoua S., and Viola M. (1986) Inhibition of growth factor-induced differentiation of PC12 cells by microinjection of antibody to Ras p21. Nature 319, 680-682.

Halegoua S., Armstrong R. B., and Kremer N. E. (1991) Dissecting the mode of action of a neuronal growth factor. Curr. Top. Microbiol. Immunol. 165, 119-170.

Heasly L. E. and Johnson G. L. (1992) The $\beta$-PDGF receptor induces neuronal differentiation of PC12 cells. Mol. Biol. Cell 3, $545-553$.

Hoffman P. W. and Chernak J. M. (1994) The rat amyloid precursor protein promoter contains two DNA regulatory elements which influence high level gene expression. Biochem. Biophys. Res. Commun. 201, 610-617.

Huff K., End D., and Guroff G. ( 1981 ) Nerve growth factor-induced alteration in the response of $\mathrm{PCl} 2$ pheochromocytoma cells to epidermal growth factor. J. Cell Biol. 88, 189-198.

König G., Master C. L., and Beyreuther K. (1990) Retinoic acid induced differentiated neuroblastoma cells show increased expression of the A4 amyloid gene of Alzheimer's disease and an altered splicing pattern. FEBS Lett. 269, 305-310.

Kremer N. E., D'Arcangelo G., Thomas S. M., De Marco M., Brugge J. S., and Halegoua S. (1991) Signal transduction by nerve growth factor and fibroblast growth factor in $\mathrm{PCl} 2$ cells requires a sequence of Src and Ras actions. J. Cell Biol. 115, 809-819.

Lahiri D. K. and Robakis N. K. (1991) The promoter activity of the gene encoding Alzheimer $\beta$-amyloid precursor protein (APP) is regulated by two blocks of upstream sequences. Mol. Brain Res. 9, 253-257

Levi-Montalcini R. (1987) The nerve growth factor 35 years later. Science 237, 1154-1162.

Milward E. A., Papadopoulos R, Fuller S. J., Moir R. D., Small D., Beyreuther K., and Masters C. L. (1992) The amyloid protein precursor of Alzheimer's disease is a mediator of the effects of nerve growth factor on neurite outgrowth. Neuron 9, 129-137. 
Mobley W. C., Neve R. L., Prusiner S. B., and McKinley M. P. (1988) Nerve growth factor increases mRNA levels for the prion protein and the $\beta$-amyloid protein precursor in developing hamster brain. Proc. Natl. Acad. Sci. USA 85, 9811-9815.

Muroya K., Hattori S., and Nakamura S. (1992) Nerve growth factor induces rapid accumulation of the GTP-bound form of $\mathrm{p} 21^{\text {rats }}$ in rat pheochromocytoma PC12 cells. Oncogene 7, 277-281.

Neve R. L., Finch E. A., and Dawes L. R. (1988) Expression of the Alzheimer amyloid precursor gene transcripts in the human brain. Neuron 1, 669-677.

Ohyagi Y. and Tabira T. (1993) Effect of growth factors and cytokines on expression of amyloid $\beta$-protein precursor mRNAs in cultured neural cells. Mol. Brain Res. 18, 127-132.

Qiu M. and Green S. H. (1992) PC12 cell neuronal differentiation is associated with prolonged $\mathrm{p} 21^{\text {ras }}$ activity and consequent prolonged ERK activity. Neuron 9, 705-717.

Quon D., Catalano R., and Cordell B. (1990) Fibroblast growth factor induces $\beta$-amyloid precursor mRNA in glial but not neuronal cultured cells. Biochem. Biophys. Res. Commun. 167, 96102.

Quon D., Wang Y., Catalano R., Scardina J. M., Kurakami K., and Cordell B. (1991) Formation of $\beta$-amyloid protein deposits in brains of transgenic mice. Nature 352, 239-241.

Rabin S. J., Cleghon V., and Kaplan D. R. ( 1993 ) SNT, a differentiation-specific target of neurotrophic factor-induced tyrosine kinase activity in neurons and $\mathrm{PC} 12$ cells. Mol. Cell. Biol. 13, 2203-2213.

Refolo L. M., Salton S. R. J., Anderson J. P., Mehta P., and Robakis N. K. (1989) Nerve and epidermal growth factors induce the release of the Alzheimer amyloid precursor from PC12 cell cultures. Biochem. Biophys. Res. Commun. 164, 664-670.

Rodriguez-Viciana P., Warne P. H., Dhand R., Vanhaesebroeck B., Gout I., Fry M. J., Waterfield M. D., and Downward J. (1994) Phosphatidylinositol-3-OH kinase as a direct target of Ras. $\mathrm{Na}$ ture 370, 527-532.

Salbaum J. M., Weidemann A., Lemaire H., Masters C. L., and Beyreuther K. ( 1988 ) The promoter of Alzheimer' disease amyloid A4 precursor gene. EMBO J. 7, 2807-2813.
Schlessinger J. ( 1993) How receptor tyrosine kinases activate Ras. Trends Biochem. Sci. 18, 273-275.

Selkoe D. J. ( 1994 ) Cell biology of the $\beta$-amyloid protein precursor and the mechanism of Alzheimer disease. Annu. Rev. Cell Biol. 10, 373-403.

Szeberényi J., Cai H., and Cooper G. M. ( 1990) Effect of a dominant inhibitory Ha-ras mutation on neuronal differentiation of PC12 cells. Mol. Cell. Biol. 10, 5324-5332.

Thomas S. M., DeMareo M., D'Arcangelo G., Halegoua S., and Brugge J. S. (1992) Ras is essential for nerve growth factorand phorbol ester-induced tyrosine phosphorylation of MAP kinases. Cell 68, 1031-1040.

Togari A., Baker D., Dickens G., and Guroff G. (1983) The neuritepromoting effect of fibroblast growth factor on PC12 cells. Biochem. Biophys. Res. Commun. 114, 1189-1193.

Trejo J., Massamiri T., Deng T., Dewji N. N., Bayney R. M., and Brown J. H. (1994) A direct role for protein kinase C and the transcription factor Jun/AP-1 in the regulation of the Alzheimer's $\beta$-amyloid precursor protein gene. J. Biol. Chem. 269, $21682-21690$

Troppmair J., Bruder J. T., App H., Cai H., Liptak L., Szeberényi J., Cooper G. M., and Rapp U. R. (1992) Ras controls coupling of growth factor receptors and protein kinase $\mathrm{C}$ in the membrane to Raf- 1 and b-Raf protein serine kinases in the cytosol. Oncogene 7, 1867-1873.

Warne P. H., Rodriguez-Viciana P., and Downward J. (1993) Direct interaction of Ras and the amino-terminal region of Raf- 1 in vitro. Nature 364, 352-355.

Wood K. W., Sarnecki C., Roberts T. M., and Blenis J. (1992) Ras mediates nerve growth factor receptor modulation of three signal-transducing protein kinases: MAP kinase, Raf-1, and RSK. Cell 68, 1041-1050.

Yoshikai S., Sasaki H., Doh-ura K., Furuya H., and Sakaki Y. (1990) Genomic organization of the human amyloid beta-protein precursor gene. Gene 87, 257-263.

Yoshikawa K., Aizawa T., and Hayashi Y. (1992) Degeneration in vitro of post-mitotic neurons overexpressing the Alzheimer amyloid protein precursor. Nature 359, 64-67. 